\title{
Postmodernistyczne wymazywanie Zagłady (Raymond Federman, Georges Perec, Anatol Ulman)
}

\begin{abstract}
Tomczok Marta, Postmodernistyczne wymazywanie Zagłady (Raymond Federman, Georges Perec, Anatol Ulman) (Postmodern Erasing of the Shoah [Raymond Federman, Georges Perec, Anatol Ulman]). "Poznańskie Studia Slawistyczne" 12. Poznań 2017. Publishing House of the Poznan Society for the Advancement of the Arts and Sciences, pp. 299-315. ISSN 2084-3011.

The article presents three strategies elaborated in the seventies of the last century by the postmodern prose, in order to tell us about the genocide. To name these strategies, the authoress makes use of the terms of blurring, patch, and "sous rapture", which serve discussing Double or Nothing by Raymond Federman, W, or the Memory of the Childhood by Georges Perec, and Cigi de Montbazon by Anatol Ulman. The essential part in the discussion on the genocide is the reception of the above mentioned novels reconstructed among others on the base of works by Susan Rubin Suleiman along with her conception of the "1.5 generation". The article also aims at a presentation of the interference between Cigi de Montbazon and European postmodernism exposed in Brian McHale's idea of "worlds under erasure". It is worth adding that the indicated presentation has not been yet considered.
\end{abstract}

KeYworD: Holocaust; postmodernism; testimony; play, rhetorical figures; narrative

Według Susan Rubin Suleiman, Raymond Federman (1928), Anatol Ulman (1931) i Georges Perec (1936) należą do pokolenia „1,5”, czyli dzieci Holokaustu, „zbyt niedojrzałych, aby zrozumieć, a często i zapamiętać, co się im przytrafiło, lecz wystarczająco dorosłych, aby przeżyć nazistowskie prześladowania Żydów" (Suleiman 2008: 179). Ich wspomnienia najczęściej krążą wokół pustki, milczenia i utraconych obrazów dzieciństwa oraz problemu natury estetycznej - jak je opisać (Suleiman 2008: 184)?

W przeciwieństwie do Suleiman, będą mnie interesować przede wszystkim postmodernistyczne wyznaczniki tej literatury. To, co Suleiman przedstawia jako wyrazisty, wręcz ostry eksperyment, w moim przekonaniu prowadzi ku obrazom przeszłości niewidocznej i zaprzeczonej, 
w których nieistotne są wspomnienia, a ich rolę przejmuje wyobraźnia w taki sposób, jak o tym pisał Federman w Uśmiechach na placu Waszyngtona 1995 roku (Federman 2002).

Wymazywanie Zagłady, zmierzające ku przedstawieniu wspomnień o niej połączonych z fantazjami na temat niepamięci, chciałabym pokazać na przykładzie trzech różnych projektów pisarskich: Federmana (Zagłada jako zamazywanie), Pereca (Zagłada jako zamglenie) i Ulmana (Zagłada jako zwątpienie). Wszystkie należą do prozy postmodernistycznej, opartej na podobnych założeniach formalnych, spośród których najważniejsze wydaje się zerwanie z ciągłością opowieści na skutek pomnożenia opowiadanych fabuł (Perec, Federman), rozszerzenia perspektywy narracyjnej na kolejne osoby gramatyczne (Federman), obnażenia fikcyjności opowieści (Ulman) oraz poddania w wątpliwość wartości pamięci (Ulman, Perec, Federman). Równie często można w tej prozie spotkać elipsy (Perec), metonimie (Federman), enumeracje (Perec), a przede wszystkim metalepsy, które sam Federman nazywał „żabimi skokami” (Suleiman 2008: 309), Brian McHale tłumaczył je z kolei jako przeskoki między ontologicznymi poziomami tekstu (McHale 2012: 172).

Cigi de Montbazon Ulmana jest spośród omawianych tu narracji opowieścią najkrótszą, ale i najważniejszą, ponieważ dochodzi w niej do głosu postmodernistyczny dyskurs Zagłady w Polsce. W latach siedemdziesiątych XX wieku przestał on być już tylko alternatywą i stał się wspólnym dziełem światowej klasy pisarzy.

\section{Zamazana Zagłada: podróż w drugą stronę}

Wydana w tym samym roku co Księga Daniela Edgara Laurence'a Doctorowa eksperymentalna powieść Raymonda Federmana Podwójna wygrana jak nic (1971) stanowi w pewnym sensie historię żydowskiego emigranta, który po przyjeździe do Stanów Zjednoczonych podejmuje heroiczną (bądź heroikomiczną) próbę opisania losów swoich i rodziny. Jest to próba przypominająca gry postmodernistów stylem organizacji materiału autobiograficznego. W 1966 roku Federman, autor pierwszej monografii na temat wczesnych powieści Samuela Becketta, otrzymał stypendium Guggenheima we Francji, miał tam napisać „drugą monografię, tym 
razem o najnowszych trendach w poezji francuskiej" (Kutnik 2010: VI). Na statku zaczął jednak pracować nad powieścią, którą skończył dwa lata później. Tematem Podwójnej wygranej... uczynił podróż w odwrotnym kierunku, z Francji do Stanów Zjednoczonych, którą musiał przebyć, aby osiedlić się po wojnie na stałe w Nowym Świecie. Wspominając, że jest to przede wszystkim dobry temat na powieść, Federman zdyskredytował swój pomysł i uczynił go przedmiotem parodii. Trudno więc byłoby czytać Podwójna wygrana ... jak opowieść o niedolach emigranta.

Tłumacząc przyczyny, z powodu których Federman nie znalazł się w ścisłym kanonie literatury Zagłady razem z Primo Levim, Jeanem Amérym, Tadeuszem Borowskim, Charlotte Delbo, Jorge Semprúnem i Elie Wieselem, Susan Rubin Suleiman wskazała na postmodernistyczny charakter jego świadectw, komplikujący ich dokumentarny charakter, oraz fakt, że w przeciwieństwie do rodziców i dwu sióstr pisarz nie został deportowany do Auschwitz i uniknął losu, który spotkał na przykład Leviego czy Wiesela. Wszystko, co Federman mógł mieć do powiedzenia na temat Zagłady, musiało więc dotyczyć szafy, w której przetrwał spotkanie z francuską policją (Suleiman 2011: 2016).

Niemniej zastanawiająca wydaje się przyczyna, z powodu której Federmana $\mathrm{z}$ grona postmodernistów wyłączyła Linda Hutcheon. W pracy A Poetics of Postmodernism: History, theory, fiction (1988) autor The Voice in the Closet wraz z Sukenickiem znalazł się wśród pisarzy spokrewnionych z twórcami francuskiej nowej powieści - Robbe Grilletem i Jeanem Ricardou. W jego „ekstremalnej metafikcji” Hutcheon (1991: 52) zobaczyła romantyczne i modernistyczne założenia, o których Federman miał wypowiadać się z pewnością siebie niespotykaną w dyskursie postmodernistycznym. Według Suleiman Federman i inni surfikcjonaliści zostali przez Hutcheon pozbawieni prawa miejsca w kanonie postmodernistycznym, ponieważ ich pisarstwu zabrakło charakteru historycznego. Określenia takie jak „,późnomodernistyczny ekstremizm” i ,,autoteliczna refleksyjność", którymi posłużyła się autorka Narcissistic Narrative: The metafictional paradox, stały się, zdaniem Suleiman, rodzajem inwektywy, która pisarstwo Federmana wypchnęła poza jeden (zagładowy) i drugi (postmodernistyczny) kanon jednocześnie.

Tymczasem proza Federmana opisuje doświadczenia wspólne wielu dzieciom, które przeżyły Zagładę, a jej eksperymentalność mieści się 
w granicach świadectwa ocalonego. W szkicu When postmodern play meets survivor testimony (2011) badaczka, porównując wczesną twórczość Federmana ze świadectwami innych ocalonych, należącymi do światowego kanonu, zwróciła uwagę, że jej formalna orygialność wynika ze sposobu przeżycia traumy przez pisarza i można ją opisać za pomocą teorii Zygmunta Freuda, Donalda Woodsa Winnicota oraz Jacquesa Lacana, a szczególnie za pomocą koncepcji fort-da, thumaczącej zachowania dziecka w odpowiedzi na oddalenie od matki. Twórcza i bardzo rozwinięta wyobraźnia Federmana poddała przetworzeniu głos narracyjny, który dzieląc się i rozpadając na drobniejsze głosy, pozostał jednocześnie konsekwencją tamtego, dziecięcego odseparowania. Jako przykład podobnego rozwiązania narracyjnego Suleiman podała bohatera-narratora Take it or Leave it, występującego jako Ja i MOINOUS. To drugie imię oznacza dosłownie związek „Me” nad „We”, czyli „mnie” i „nas”, który w biografii Federmana wskazuje na niego samego i zamordowaną w Auschwitz rodzinę (Suleiman 2011: 219).

Zdaniem Suleiman, eksperymenty tego autora, przez które badaczka rozumie nie tylko prozę konkretną i multiplikację narratorów, lecz także językowe paradoksy, szczególny humor oraz śmiałe opisy seksu, są wyrazem jego wczesnodziecięcej traumy, która podobnie jak Pereca, innego przedstawiciela pokolenia „1,5” wśród francusko-żydowskich pisarzy, prowadzi Federmana w kierunku „ukośnej” i niebezpośredniej reprezentacji Zagłady.

Psychoanalityczne nachylenie badań Suleiman sprawiło, że sięgnęła ona po wczesne Federmanowskie paradoksy i odczytała je jako próbę wypowiedzi na temat tego, co pisarz chciał w swoim życiorysie jednocześnie ukryć i pokazać (,saying while not saying”; Suleiman 2011: 220). Najbardziej znanym przykładem tej sprzeczności są cztery znaki „X” umieszczone w Take It or Leave It obok siebie i oznaczające zamordowanych rodziców oraz siostry; innym - gwiazda Dawida, ułożona ze zdań tworzących narrację. Brain McHale nazwał je ideogramami Holokaustu (McHale 2012: 264-265).

Suleiman, aby wzmocnić efekt powagi ideogramów, porównała je do Lacanowskiej „dziury w rzeczywistości”, powstałej po śmierci kogoś bliskiego (kochanego) (Lacan 1977: 55-56, 11-52). Puste miejsca w tekście oraz wizualna reprezentacja Zagłady wskazują na niechęć Federmana, aby tę pustkę wypełnić. Enumeracje, słowne gry i repetycje stwarzają odwrotny 
efekt, który wiąże się z freudowską koncepcją fort-da. Istota paradoksów, rozrzuconych pomiędzy kilkoma piętrami narracji, polegałaby zatem na uchwyceniu zamiaru jednoczesnego zacierania i odkrywania przeszłości, który stanowi echo dziecięcej traumy (Suleiman 2011: 223).

W pracy Crises of Memory and the Second World War (2008) Suleiman zestawiła ze sobą biografie Pereca i Federmana oraz ich dwie powieści, $W$ albo wspomnienie dzieciństwa oraz Podwójna wygrana... Oprócz wielu podobieństw różni je koncepcja wspomnianej już luki. Perec widzi zamiast przeszłości pustkę, Federman opisuje natomiast Zagładę jako eksces, łącząc ją ze specyficznym poczuciem humoru i pornografią (Suleiman 2011: 202). Narracyjną predylekcję, którą znajduje Suleiman w Podwójnej wygranej..., aby pokazywać nadmiar i brak związany z doświadczeniem przeszłości, nazywa paralipsą, wewnętrznie sprzeczną figurą retoryczną polegającą na afirmacji i negacji, unikaniu i ujawnianiu, amnezji i pamiętaniu jednocześnie. Paralipsa oznacza bardzo precyzyjnie zapamiętaną sytuację bądź doświadczenie (w Podwójnej wygranej... są to zwykle obozy zagłady), o której narrator jednak nie mówi, zamiast tego stosując różne inne, kojarzące się z nią określenia.

Posługując się terminologią Charlesa Pierce'a, Suleiman nazywa ocalonego i jego doświadczenie indeksem, tłumacząc, że podobnie jak ocalony, indeks nie mówi, musi więc zostać poddany interpretacji. Indeksalny charakter literatury Zagłady, który w innym miejscu porównałam do metonimii (Cuber 2013), wynika z ogólnego przekonania, które patronuje wszystkim wypowiedziom Suleiman na temat Federmana i roli wyobraźni w literaturze o Holokauście. Powołując się na stwierdzenie autora Uśmiechów na Placu Waszyngtona, Suleiman twierdzi, że fikcyjne pisarstwo jest naturalnym następstwem literatury świadków, i przypomina w tym kontekście dwie powieści oparte na fikcyjnym i jednocześnie prawdziwym doświadczeniu, Anne Michaels Fugative Pieces (1996) i Austerlitz Winfrieda Georga Sebalda (2001). Obie, chociaż napisane przez autorów niezwiązanych bezpośrednio z Zagładą, stanowią przykład prozy, która naśladuje i stwarza możliwości świadectwa.

Zdaniem Sue Vice późniejsza o osiem lat od Podwójnej wygranej... nowela Glos w szafie z 1979 roku stanowi splot dwu form narracyjnych: testymonialnej i eksperymentalnej, za które odpowiedzialne są dwa, konkurujące między sobą, głosy narratora (Federman 1989). Jeden z nich 
należy do chłopca, który ostatni raz widział matkę, mając czternaście lat. Drugim głosem przemawia dorosły pisarz, obserwujący i opisujący tamto dziecko. Wiążą się z tym dwie różne reprezentacje przeszłości: ozdobny język dziecka i metafory, po które sięga dorosły, spotykające się w rozsianych w twórczości Federmana obsesyjnych obrazach bycia zamkniętym (Vice 2004: 59). Vice porównuje je do Bachtinowskiego chronotopu, który w obu przypadkach, Federmana i Dostojewskiego, oznacza przestrzeń graniczną, odnowy, epifanii, ale i zagrożenia (Vice 2004: 59-60). Bezradność dorosłego wobec doświadczenia Zagłady dziecka jest nieusuwalna. Dorosły ulega wspomnieniom o przeżyciach sprzed lat, cytując i interpretując tę bezradność; oba głosy, dziecięcego narratora i narratora-pisarza mieszają się i przeplatają, a ich rozróżnienie, jak próbuje to czynić Vice, jest czasem niemożliwe. Tak jak w tym fragmencie:

I register the final absence of my mother crying softly in the night my father coughing his blood down the staircase they threw sand in their eyes struck their back kicked them to exterminate them his calculations yes explanations yes the whole family parenthetically xxxx into typographic symbols... (Federman 1989).

O przemieszczeniach Ja między aktualną i wirtuaną osobą narracyjną pisze Federman, najczęściej zmieniając podmiot oraz narrację z pierwszoosobowej na trzecioosobową, co z kolei prowadzi do zmian w obrębie świadectwa. Na przykład:

a survivor who dissolves in verbal articulations unable to do what I had to do admit that his fictions can no longer match the reality of my past... (Federman 1989).

Uwagi Suleiman na temat prozy Federmana można rozszerzyć o wspomnianą już grę z narracją testymonialną. Narrator Podwójnej wygranej... nie przestrzega paktu autobiograficznego, który wcześniej zawiązał między sobą i czytelnikiem, ale łamiąc go i zmieniając imiona bohaterów, szczegóły ich biografii, a przede wszystkim samą opowieść, ukazuje świadectwo jako formę spetryfikowaną i schematyczną (Federman 2010: 156). Rozbić i zdemontować może ją jednak nie prawda, ponieważ jej dowieść się nie da (,ale co się zdarzyło naprawdę to jest najważniejsze pytanie CO SIĘ ZDARZYŁO NAPRAWDĘ?"), lecz eksces. Takim ekscesem zarówno w Głosie w szafie, jak i w Podwójnej wygranej... jest masturbacja. Oto w fikcyjnej historii o losach Borisa, żydowskiego uciekiniera z transportu, 
Federman umieszcza scenę, gdy bohater zostaje przygarnięty przez farmera i tuż po wejściu do pokoju „wytrzepał kapucyna, a raczej zaczynał trzepać trzymając go w lewej dłoni, kiedy nagle zobaczył samego siebie w lustrze..." (Federman 2010: 136).

Dopiero szczegółowy, powtórzony kilkakrotnie opis zbliżenia seksualnego między Borisem a czarnoskórą Amerykanką uświadamia przywiązanie Federmana do postmodernistycznej opowieści o Zagładzie. Daje mu ona szansę wielokrotnego i niekończącego się fantazjowania o przeszłości, które z jednej strony odgrywa rolę autoterapii, z drugiej stanowi rozwiązanie dylematu wynikającego z pytania, jak opowiadać o śmierci rodziców.

Zamazywanie Zagłady, do którego zmierza Federman, widoczne, często dosłownie, w postaci narracyjnych układów figuralnych, charakterystycznych dla powieści konkretnej, ale i dla bezpośrednich deklaracji, nie jest w rzeczywistości jedynym sposobem na wyrażenie refleksji związanych z eksterminacją rodziny, jaki znaleźć można w Podwójnej wygranej... Równie ważne wydają się próby, podejmowane przez dojrzałego już narratora, odtworzenia i zrozumienia sytuacji zamknięcia, której doznało kilkunastoletnie dziecko. Celowo nie piszę o przypominaniu tamtych przeżyć, ponieważ wydaje się, że bohater-narrator ich nie pamięta i nie chce sobie przypomnieć. A jeśli cokolwiek, oprócz bazy materialnej, stara się stworzyć bądź odtworzyć przed zamknięciem przez 365 dni, to jest to wyobrażanie sobie sytuacji ekstremalnej sprzed lat.

Oddalając się od „pierwotnego zdarzenia”, autor To Whom it may Concern paradoksalnie zbliża się do niego. Właśnie tak, jak uczynił to, płynąc statkiem z Ameryki do Francji i pisząc powieść o podróży w drugą stronę.

\section{Zamglona Zaglada}

Po metodę Federmana, aby opisać wojenną kryjówkę z pozycji współczesnej, skonstruowanej na kształt fikcji przypominającej rzeczywistość, nie sięgnął Georges Perec w autobiografii z 1975 roku. Jego wspomnienia zdają się prostsze i jednopłaszczyznowe. Ale to jedynie pozory, ponieważ w prozie $W$ albo wspomnienie $z$ dzieciństwa autor Rzeczy wykreował zawiłą i nieoczywistą opowieść o przeszłości, wychodząc z założenia, że o TYM trzeba pisać, ale napisać nie można za wiele. 
Jak twierdzi Susan Suleiman, eksperyment formalny $W$ albo wspomnienia z dzieciństwa różni się od formalnej ekstrawagancji La disparition z 1969 roku, powieści bez, najczęściej używanej w języku francuskim, samogłoski „e”. Podwojenia, nieciągłość, brak i nieobecność są w niej przepojone dziecięcą traumą i separacją od rodziców (Suleiman 2008: 197). Publikacja nie tylko zaskoczyła czytelników Pereca, ale całkowicie zmieniła obraz jego twórczości. Perec zadedykował $W$ albo wspomnienie... osobom ukrytym pod literą „E”, czyli rodzicom, odsłaniając jednocześnie to wszystko, co próbował zamazać w La disparition. Zagłada stała się odtąd nieodzownym kontekstem jego twórczości i wielu formalnych eksperymentów.

Jeden z nich bezpośrednio dotyczy tytułu opowieści z 1975 roku. Litera „W”, zwłaszcza w języku angielskim, oznacza podwojenie, a zatem i podwójną reprezentację. Suleiman wiąże ją z tradycją tytułowania opowiastek osiemnastowiecznych w rodzaju: Kandyd czyli optymizm bądź Tartuffe albo świętoszek. W przypadku wspomnień Pereca chodzi o jeszcze inne znaczenie litery - „W” to tajemnicza przestrzeń, w której rozgrywają się zdarzenia przypominające zawody sportowe w starożytnej Sparcie. Suleiman porównuje ją do opowieści Juliusza Verne'a. Przypomnijmy, że druga, równoległa i alternatywna opowieść, tworząca postmodernistyczną grę i dystopię jednocześnie, bierze początek w spotkaniu głównego bohatera z Gaspardem Wincklerem, człowiekiem, który twierdzi, że znał chłopca o tym samym imieniu i nazwisku, które nosi bohater-narrator. Tajemnicze pojawienie się Wincklera i zniknięcie wspomnianego chłopca, chorowitego syna śpiewaczki, który podczas rejsu statkiem prawdopodobnie schodzi na ląd i oddala się na zawsze od matki, to wątki, które Perec wiąże z opowieścią o wyspie W. Spartańska dyscyplina obowiązująca jej mieszkańców z wolna zaczyna przypominać nazistowski terror, aż w końcu rozpoznajemy w Atlecie, anonimowym bohaterze historii, więźnia obozu koncentracyjnego. Opowieść Pereca kończy się przejmującą fantazją na temat mienia pożydowskiego:

Ten, kto pewnego dnia zapuści się we wnętrze Fortecy, napotka najpierw amfiladę długich, szarych sal. (...) ale długo będzie musiał iść, nim odkryje spoczywające głęboko pod ziemią szczątki świata, który wydawał mu się już zapomniany: stosy złotych zębów, obrączek, okularów, sterty z tysięcy ubrań, zakurzone kartoteki i zapasy podłej jakości mydła (Perec 2014: 198). 
Sportowa fantazja, osadzona na wyspie przypominającej Ziemię Ognistą (Perec 2014: 200), wzięła się z opracowania Davida Rousseta Świat obozów koncentracyjnych i wyrażonej tam opinii na temat podobieństwa sportu i pracy przymusowej. Jej znaczenie trudno jednak sprowadzić do rozwinięcia wybranych wątków książki Rousseta. Perec napisał alternatywną opowieść, która razem ze szczątkowymi i „wyblakłymi” wspomnieniami z części pierwszej, dotyczącymi jego rodziny, tworzy postmodernistyczną reprezentację Zagłady, opartą na złożonym rozumieniu przeszłości, w którym pojawiają się refleksje na temat niewydolności literatury i pamięci oraz niemała garść wspomnień, zapisanych w sposób daleki od linearności, jaką pamiętamy z książki Haliny Birenbaum¹. Zdaniem Philippe'a Lejeune'a (1991: 39), przed Perekiem nikt nie pisał tak „zmontowanej” retrospektywy.

To, co Lejeune nazwał w odniesieniu do $W$ albo wspomnienia $z$ dzieciństwa autobiografią krytyczną, można by również nazwać autobiografią postmodernistyczną. Złożyły się na nią napisana w 1959 roku osobista część wspomnień Pereca oraz, wspomniana wyżej, opowieść science fiction, opublikowana na łamach „La Quinzaine Littéraire” w 1969 roku.

Istotą autobiografii krytycznej jest jednak nie to, że została „zmontowana" z rozmaitych surowców narracyjnych, ale to, że istnieją w niej równocześnie opowieść o życiu i dekonstruująca ją refleksja. W przypadku wspomnień Pereca byłaby to hiperboliczna refleksja na temat braku wspomnień z dzieciństwa oraz ich rekonstrukcja. Całość przypomina Federmanowski paradoks znany pod nazwą saying without saying. Suleiman wiąże go przede wszystkim z wątpliwością, jak pisać o Holokauście, towarzyszącą porównywanym pisarzom. Najbardziej oczywistym przykładem tej wątpliwości jest, jej zdaniem, wielokropek postawiony między pierwszą i drugą częścią wspomnień, który metonimizuje Zagładę bądź jej niewypowiadalność. Decyzję, co naprawdę oznacza ta elipsa, Warren Motte nazwał kluczem do zrozumienia tej książki (Suleiman 2008: 199).

\footnotetext{
${ }^{1}$ Chodzi o poświęcony pobytowi autorki w obozach na Majdanku, Auschiwtz, Ravensbrück i Neue Stadt Glewe tom wspomnień Nadzieja umiera ostatnia. O książce Birenbaum jako układzie odniesienia dla rozwijającej się od połowy lat sześćdziesiątych XX wieku polskiej prozy o Zagładzie piszę w przygotowywanej monografii na temat związków literatury postmodernistycznej z Zagładą.
} 
Zatrzymajmy się przez chwilę na postmodernistycznych cechach $W$ albo wspomnienia $z$ dzieciństwa. Jako fantastyka naukowa opowieść Pereca jest tym, co McHale nazwał ,gatunkiem ontologicznym par excellance", porównując science fiction do powieści detektywistycznej, która odegrała podobną rolę w modernizmie. Między obydwoma typami opowieści występującymi w autobiografii Pereca, następuje interferencja, która powoduje, że pozostają one wobec siebie w stosunku metafory bądź metonimii (Suleiman nie precyzuje, o jaką figurę retoryczną jej chodzi [Suleiman 2008: 202]). Warto pamiętać również o crisscross web, czyli paralelach między pierwszą a drugą częścią książki, które Suleiman nazywa bardzo różnie, m.in. rekursją i chiazmami (Suleiman 2008: 202).

Za postmodernistyczny można uznać również kluczowy paradoks $W$ albo wspomnienia... głoszący potrzebę pisania w obliczu braku słów i wspomnień. Uwypukleniu go służy treść VIII rozdziału, który ma najwyższą wartość dokumentarną i zarazem największy potencjał krytyczny. Wraca w nim Perec do dawnych, implementowanych w obszar tekstu głównego, opisów matki i ojca, zaznaczając je pogrubioną czcionką, a następnie komentując ich znaczenie w nowych przypisach. Część z nich jest korektą nazwisk bądź uzupełnieniem dat z tekstu głównego, pozostałe tworzą osobne historie.

O ojcu, Icku Judko, terminującym przed 1926 rokiem u warszawskiego kapelusznika, Perec napisał bardzo niewiele. Stracił go, mając cztery lata. Pomoc w odczytywaniu przeszłości przyniosła mu jedyna, zachowana fotografia.

Informacji na temat matki, mimo posiadania pięciu jej zdjęć, miał Perec jeszcze mniej. Wiedział na pewno, że ,jej dzieciństwo było okropne i pozbawione historii. Urodzona w roku 1913 [w Warszawie - M.T.], musiała dorastać podczas wojny. Do tego była ubogą Żydówką. Na pewno musiała nosić łachy po sześciorgu starszego rodzeństwa..." (Perec 2014: 41). Dlatego zdecydował się usunąć ze swoich wspomnień, wprowadzone wcześniej jako hipotezę, okrucieństwo, i pokazać matkę „w bladej poświacie", przypominającą bohaterki Dziewczynki z zapałkami Jana Christiana Andersena i Nędzników Victora Hugo:

Kiedy o niej myślę, staje mi przed oczami kręta uliczka gdzieś w żydowskiej dzielnicy, skąpana w bladej poświacie, może przysypana śniegiem, a przy niej nędznie oświetlone sklepiki, przed którymi stoją niekończące się kolejki. Moja mama, takie maleńkie nic, 
wysoka jak Tomcio Paluszek, zakutana po nos w chustę zrobioną na drutach, targa za sobą czarny koszyk, ze dwa razy od niej cięższy (Perec 2014: 42).

Moment, na jaki wskazują te hipotetyczne wspomnienia, z punktu widzenia reprezentacji czasów Zagłady w prozie postmodernistycznej lat siedemdziesiątych, wydaje się kluczowy. Oto urodzony w 1936 roku pisarz, bardzo wcześnie osierocony, określa problem związany z opisem przeszłości całkowicie inaczej niż byśmy się spodziewali. Nie są to zmagania z opowiedzeniem Zagłady, bo i nie ona znajduje się w bezpośrednim doświadczeniu Pereca, ale z czymś, co działo się wokół niej, na jej obrzeżach, na kilka lat przed Holokaustem albo tuż przed jego początkiem. Zamglona i blada Zagłada w świetle wspomnień Pereca, niczym paradoks, zdaje się obrazem, przez który przeziera ledwie widoczny wizerunek najbliższych, z których jedno zginęło w 1940 roku, a z drugim Perec, wówczas sześcioletni chłopiec, pożegnał się w 1942 roku.

Nie wiem, czy naprawdę nie mam nic do powiedzenia - wiem, że nie mówię. Nie wiem, czy to, co miałbym do powiedzenia, nie zostało wypowiedziane, ponieważ jest niewyrażalne (nie chodzi tu o ograniczenia pisarskie, lecz o niewyrażalność tego, co stało się powodem pisania) - wiem, że to, co piszę, jest przejrzyste, blade, bez znaczenia i raz na zawsze to unicestwia (Perec 2014: 52-53).

Zwiększona liczba zaimków wskazujących i nieokreślonych („to”) w przywołanym fragmencie oznacza, że podobnie jak Federman Perec znalazł zastępczy sposób mówienia o przeszłości. Jednak w przeciwieństwie do autora Podwójnej wygranej... nie chodzi w nim ani o eksperyment, ani o zastąpienie rzeczy symbolem (preteritio). Perec jest od Federmana bardziej powściągliwy w słowach, ale nie w emocjach, a w tym, co ostatecznie mówi, nie zachowuje żadnych retorycznych reguł z konsekwencją znamienną dla Take It or Leave It. Oprócz paradoksalnego stwierdzenia, którym kończy VIII rozdział: ,ich [rodziców] wspomnienie umiera w pisaniu, a pisanie jest wspomnieniem ich śmierci i potwierdza, że ja żyję" (Perec 2014: 53).

\section{Zaglada sous rature}

Trzecie wydanie Cigi de Montbazon Anatola Ulmana ukazało się ze wstępem Krzysztofa Uniłowskiego. Wprawdzie Zagłady dotyczy nie cała 
powieść, ale jej krótki, kilkustronicowy fragment, odnieśmy jednak wypowiedź krytyka, napisaną jako komentarz o charakterze ogólnym i wprowadzającym do eksterminacji Żydów i tego, co można nazwać jej literacką reprezentacją:

Niemoc? Nieprawomocność? Ależ właśnie dlatego nie milczeć, lecz opowiadać należy! Gdy świat okazuje się nieprzejrzysty (...), wówczas opowiadaniu przypada rola szczególna. Nie odkrywa ono żadnej prawdy, nie daje wiedzy, nie uczy żadnych użytecznych umiejętności, niczego nie upamiętnia - wszystkie te stare złudzenia i uroszczenia Ulman wykpiwa. Ale też pokazuje, że w takiej właśnie sytuacji opowiadanie staje się jedynym dowodem, a przynajmniej - poszlaką przemawiającą za istnieniem świata i tego, kto opowiada (Uniłowski 2001: 5).

W świetle wyznań Pereca („wiem, że nie mówię”) wypowiedź Uniłowskiego wydaje się co najmniej niestosowna. Opowiadanie, jak wynika z wcześniejszych uwag na temat literatury o Zagładzie, ma bowiem wartość faktograficzną i sprawozdawczą, stanowi odniesienie (bezpośrednie bądź nie) do rzeczywistych zdarzeń, może pełnić funkcję dowodu zbrodni, a przede wszystkim dźwigać ciężar czyjegoś życia. Jeżeli jest to opowiadanie pierwszoosobowe - dźwiga ciężar życia ocalonego. $Z$ wypowiedzi Uniłowskiego można jednak wyczytać, że opowiadanie nie tylko żadnego ciężaru nie dźwiga, ale w ogóle nie dotyczy rzeczywistości. Opowiadanie to dowód sam w sobie. Uniłowski zarysowuje jeszcze jedną możliwość jego rozumienia. Można ją nazwać pustą metonimią. Opowiadanie potrafi stworzyć iluzję reprezentacji, jest to jednak tylko iluzja. Tak naprawdę do niczego nie odsyła, nic nie osłania i nie skłania do wyobrażeń o strukturze narracji jako powłoce, pod którą kryje się jakiś dramat docierający do odbiorcy za pomocą środków niebezpośredniego wyrażania. Mnie tymczasem zależy na pokazaniu, że Ulman rozwinął w powieści z 1979 roku radykalny sposób mówienia o przeszłości, złożony nie tylko z hipotez, ale po prostu z zaprzeczeń, których w dosłownie czytanym świadectwie być nie może, zwłaszcza jeżeli jest ono reprezentacją czasów II wojny światowej.

Wstęp do Cigi de Montbazon napisany przez Uniłowskiego w wielu miejscach przypomina Surfikcje - cztery propozycje $w$ formie wstępu Raymonda Federmana, szkic pochodzący z książki wydanej w 1975 roku. Jedna z jej tez głosi, że: 
Jedyną prozą (...), która wciąż jeszcze ma jakieś znaczenie, jest proza usiłująca zbadać możliwości fikcji literackiej. (...) Taką prozę nazywam surfikcją. Nie dlatego jednak, że naśladuje rzeczywistość, lecz dlatego, że ujawnia jej fikcyjność (Federman 1983: 423).

W opowieści trzynastoletniego Franciszka - obejmującej czasy wojny (od 1 września 1939 roku do wybuchu powstania warszawskiego) i dzieje jego najbliższej rodziny, związane w sposób szczególny z magicznym ogrodem stanowiącym coś w rodzaju przedmurza chroniącego mieszkańców przed wpływami historii - pojawia się postać pana Belta i jego dzieci. Jest to postać epizodyczna o dość niewielkim znaczeniu i być może właśnie dlatego Uniłowski, który wprawdzie ją dostrzega, nie rozwija stwierdzenia o „niearyjskim pochodzeniu” bohatera, poprzestając na zastanawiającej parafrazie. Odsyła ona do bogatego żydowskiego urzędnika bankowego, jego żony i dwojga bliźniąt, których zabawy stanowią obiekt fascynacji i zazdrości Franciszka. Oba wspomniane afekty tematem swojej wypowiedzi o Cigi de Montbazon uczynił Krzysztof Kłosiński. Refleksja o pożądaniu zaprowadziła go jednak w miejsce, z którego słychać słowa Maurice'a Blanchota o zastępującej rzeczywistość naturze języka (Blanchot 1996: 28-29):

Pożądanie okazuje się w ostatecznym rachunku pragnieniem unicestwienia, jego logika zna tylko logikę kata i ofiary. Jedynym wyjściem może być dewiacja, a uniwersalność tego wyjścia polega na grze metaforycznej. Zastępując obiekt pożądania jego reprezentacją, (...) dewiacja oferuje zarazem skoncentrowane w przedstawieniu (...) umieranie ofiary, umieranie przedłużone w nieskończoność (Kłosiński 2000).

Wprawdzie uwagi Kłosińskiego dotyczą zdjęć nagich kobiet, a nie Zagłady, łączy je jednak z fragmentem o dzieciach pana Belta problem pożądania, które, podobnie jak język, aby zatrzymać obiekt, musi go zniszczyć. A chce przebywać z obiektem jak najdłużej, więc za pomocą serii twierdzeń i zaprzeczeń niszczy i odtwarza go w nieskończoność. W ten sposób Ulman stwarza dogodną okazję do uczynienia z opowieści laboratorium narratologicznego, w którym fikcja i rzeczywistość zostają poddane najróżniejszym próbom i analizom. Szczególnie widać to w tym fragmencie:

Na konarze jabłoni (...) wisiała huśtawka fabrycznej produkcji a dziewczynka zakreślała na niej łuki niby wahadło czasu, a niedojrzałe owoce spadały ze starego drzewa 
i gniły, pokrywając się brązowym nalotem. Nad tym zaprzepaszczeniem jabłek Zuza robiła w powietrzu regularne powroty do miejsca opuszczonego przed chwilą, wobec tego istniała nie tylko w projekcji swojego ojca, ale także w przestrzeni, w którymś jej punkcie, na tej krzywej wymyślonej przez geometrię, taka krzywa jest jedynie pojęciem, więc w jakimś punkcie pojęcia i w jakimś czasie. Nie prowadzi to do twierdzeń oczywistych, tym bardziej że Zuza miewała mdłości od zabaw na huśtawce, dlatego nigdy nie siedziała na tym sprzęcie (Ulman 2001: 104-105).

Ulman zdaje się w tym obrazie negować wszystko, począwszy od niedojrzałych jabłek, które zaraz gniją, przez krzywą, którą zakreśla ruch huśtawki, po samo istnienie Zuzy, będące projekcją jej ojca, a przede wszystkim czymś między fantazją i wspomnieniem narratora. Momentalne negowanie istnienia, rozpiętego między „powoływaniem do życia” i „przywracaniem do istnienia”, a więc stwarzanie i odtwarzanie, odsyła nas do skreśleń, znanych z pracy Martina Heideggera i Jacques'a Derridy pod nazwą sous rature, które w powieści postmodernistycznej stosowane są jako swego rodzaju techniczna sztuczka. Wydaje się, że w przypadku Cigi de Montbazon można jednak mówić o czymś więcej niż sztuczce, a „wypieranie illokucji przez supozycje” (Uniłowski 1998: 55) oznacza Derridiańską pustkę po teraźniejszości i doświadczeniu, w odróżnieniu od której przekreślany przez Heideggera byt jest nieartykułowaną obecnością (Spivak 1997: XVII).

Warto w tym miejscu postawić karkołomne pytanie o różnice w praktyce wymazywania przeszłości między Federmanem, Perecem i Ulmanem a Heideggerem i Derridą.

Zacznijmy od Pereca, który, podobnie jak Ulman, na miejsce lekcji o skreśleniach wybiera willę. Ku refleksji na temat wymazywania Zagłady wiedzie go wspomnienie ciotki Esther i jej domu, nieopodal którego nastoletni wtedy pisarz zobaczył rąbiącego drewno człowieka siedzącego na koziołku przypominającym literę X. „Ta sama litera służy też unicestwieniu słowa, gdy skreślamy je $\mathrm{w} x$, bo nie chcieliśmy go napisać" (Perec 2014: 97). Obraz skrzyżowanych desek jak ramion jedynej w słowniku ,litery, która stała się słowem" (Perec 2014: 97), wiedzie Pereca ku myśleniu o Zagładzie ukrytej w symbolach: swastyce, SS i gwieździe Dawida. Są to „symbole związane z historią (...) dzieciństwa” (Perec 2014: 97). Stawia je jednak Perec w miejscu, w którym mógłby oddać się opowieści związanej z historią swojej żydowskiej rodziny pod rządami nazistów albo wojenną 
historią Żydów w ogóle. Symbole występują tu zamiast rzeczywistości, są więc do pewnego stopnia jej metonimią (by pozostać przy terminologii, o której kilka razy już wspomniałam).

Skreślenia w prozie Federmana służą zamaskowaniu rzeczywistości, stwarzają więc sytuację, w której mamy zostać uwiedzeni pomysłem wymazania wydarzenia pierwotnego i zaskoczeni, że towarzyszy mu wciąż zwielokrotniana i ponawiana opowieść. Idealnym sposobem jednoczesnego wykreślania i pisania okazała się dla autora Shhh. The Story of a Childhood figura znana pod nazwą praeteritio, czyli ,pominięcie, w praktyce jednak chytrze stosowane. Może być istotnie opuszczeniem rzeczy nieważnych, ale gdy jest pominięciem zapowiedzianym i oświadczonym, (...) staje się formą ironii" (Ziomek 2000: 232). Po praeteritio sięgnął Federman już na pierwszej stronie Podwójnej wygranej...:

jego rodzice (obydwoje) i dwie siostry (jedna starsza, druga młodsza od niego) zostali wywiezieni (byli Żydami) do niemieckiego obozu koncentracyjnego (chyba Auschwitz), skąd nie powrócili, bo na pewno zostali tam zgładzeni $(\mathrm{X} * \mathrm{X} * \mathrm{X} * \mathrm{X})$ (Federman 2010: 0).

Ulman proponuje bardziej skomplikowane rozwiązanie, polegające na zastosowaniu zamiast znaków typograficznych opowieści złożonej z oznajmień i zaprzeczeń, przypominającej koncepcję wymazanego świata Briana McHale'a. Oto, w jaki sposób krytyk odróżnia ją od praktyki sous rature Derridy:

Oczywiście powieści postmodernistyczne (...) nie wymazują znaczących [signifiers] w pojęciach dyskursu filozoficznego, tylko przedmioty przedstawione w wymyślonym świecie; ich celem jest (...) obnażenie procesów, w których czytelnicy konstruują fikcyjne przedmioty i światy (McHale 2012: 144-145).

Jak jednak odnieść wymazywanie fikcyjnych światów do rzeczywistości przedstawionej, którą jest Zagłada? Broniąc estetycznej wrażliwości Ulmana, Uniłowski dowodzi, że pisarz wychodzi poza modernistyczną argumentację i zamiast ujawniać ułomność literatury i rozwodzić się nad toposem niewyrażalności, pokazuje tkwiący w niej potencjał inscenizacyjny, dotyczący motywów i schematów fabularnych, i przy okazji wyraża swój sceptycyzm ontologiczny (Uniłowski 1998: 56).

Jeśli jednak spojrzeć na sous rature jak na mechanizm związany ze 
stylem odbioru, trzeba przyznać, że skreślenie nie tylko utrudnia lekturę, ale, przez sam fakt istnienia dodatkowych znaków, wzmaga ciekawość czytelnika, aby odkryć to, co przekreślone, i przywrócić zamazane istnienie do życia, a w dalszej kolejności pojąć, dlaczego ktoś zaciekle próbował je zanegować. Sous rature, podobnie jak serie zaprzeczeń i oznajmień, z którymi spotykamy się w Cigi..., stanowią element aktywnej lektury, o której w Surfikcjach... pisał Federman (1983: 426), nie zaś opowieść „o niczym”, jak twierdził Uniłowski, podążając ślad w ślad za narracją (Uniłowski 1998: 55).

Obrazy zatartych, zamglonych bądź przekreślonych wspomnień Zagłady, które znaleźć można w postmodenistycznych narracjach lat siedemdziesiątych XX wieku, stanowią residuum walki o artykulację ludobójstwa. Jej wynik nie jest przesądzony, albowiem każdy z pisarzy sięgających po reprezentację przeszłości, która sama w sobie wydaje się wątpliwa, stosuje strategię paradoksu, negującą i potwierdzającą refleksje o przeszłości jednocześnie. Gdyby chciało się pokazać między nimi różnice, należałoby powiedzieć, że Perec, Federman i Ulman wznieśli swoją twórczość poświęconą wojnie na zanegowaniu jej obecności, stwierdzeniu jej istnienia i zwątpieniu w nie. Puste i pozbawione desygnatu wydają się przede wszystkim wspomnienia Pereca. Paraliżująca mówienie potrzeba pamiętania, najsilniej rozwinięta u tego pisarza, prowadzi do smutnego wniosku: zapomnienie jest silniejsze niż miłość. Pisarz ulega mu zatem, starając się zbyt daleko nie wykraczać poza to, co zdołał zapamiętać z dzieciństwa. Federman rozstrząsa swoją pamięć w nieskończoność, stosując przeróżne techniki narracyjne, ogniskowe, osoby gramatyczne, a nawet tożsamości bohaterów. Z kolei wszystko, co czytamy w Cigi de Montbazon, jest alternatywą. Historia pana Belta jako część surfikcji może być również przyjmowana w kategoriach opowieści polskiego świadka (mogłaby na to wskazywać data narodzin pisarza), a przynajmniej kogoś, kto mógł przyglądać się wojennej rzeczywistości jako jej uczestnik i aktor jednocześnie.

\section{Literatura}

Birenbaum H., 2012, Nadzieja umiera ostatnia, Oświęcim.

Blanchot M., 1996, Wokół Kafki, przeł. K. Kocjan, Warszawa. 
Cuber M., 2013, Metonimie Zagłady. O polskiej prozie lat 1987-2012, Katowice.

Federman R., 1983, Surfikcja - cztery propozycje $w$ formie wstepu, w: Nowa proza amerykańska. Szkice krytyczne, wyb., oprac. i wstępem opatrzył Z. Lewicki, przeł. J. Anders, G. Cendrowska, A. Kołyszko et al., Warszawa.

Federman R., 1984, Głos w szafie, przeł. M. Wilczyński, „Literatura na Świecie” nr 9 (158), s. 194-214.

Federman R., 1989, The Voice in the Closet, Hamburg [b.n.s.].

Federman R., 2002, Uśmiechy na placu Waszyngtona. (Poniekąd romans), przeł. K. Walewski, Lublin.

Federman R., 2010, Podwójna wygrana jak nic. Prawdziwy fikcyjny dyskurs, przeł. J. Kutnik, Kraków.

Hutcheon H., 1991, A Poetics of Postmodernism: History, theory, fiction, London-New York.

Kłosiński K., 2000, Eros, dekonstrukcja, polityka, Katowice.

Kutnik J., 2010, Ttumacz po słowie, w: R. Federman, Podwójna wygrana jak nic. Prawdziwy fikcyjny dyskurs, Kraków.

Lacan J., 1977, Desire and the interpretation of desire in Hamlet, „Yale French Studies" nr 55-56, s. 11-52.

Lejeune P., 1991, La memoire et l'oblique: Georges Perec autobiographe, Paris.

McHale B., 2012, Powieść postmodernistyczna, przeł. M. Płaza, Kraków.

Michaels A., 1996, Fugitive Pieces, Toronto.

Perec G., 2014, W albo wspomnienie z dzieciństwa, przeł. W. Brzozowski, Kraków.

Sebald W.G., 2001, Austerlitz, London.

Spivak G.C., 1997, Acknowledgments, w: J. Derrida, Of Grammatology, Baltimore.

Suleiman S.R., 2008, Crises of Memory and the Second World War, Cambridge-Massachusetts-London.

Suleiman S.R., 2011, When postmodern play meets survivor testimony, w: Federman's Fictions. Innovation, Theory, and the Holocaust, red. J.R. Di Leo, New York.

Ulman A., 2001, Cigi de Montbazon, Koszalin.

Uniłowski K., 1998, Opowieść znaleziona na śmietniku (Cigi de Montbazon Anatola Ulmana), „Twórczość” nr 6, s. 50-58.

Uniłowski K., 2001, Wstęp, w: A. Ulman, Cigi de Montbazon, Koszalin.

Vice S., 2004, Children Writing the Holocaust, New York.

Ziomek J., 2000, Retoryka opisowa, Wrocław. 